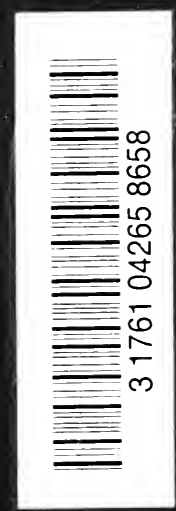

HO

23

D8

c.1

ROBA. 
Digitized by the Internet Archive in 2007 with funding from

Microsoft Corporation 



\title{
PERSONAL BEAUTY AND RACIAL BETTERMENT
}

\author{
BY \\ KNIGHT DUNLAP \\ PBOFESSOB OF EXPRRTMENTAL PSYOHOLOGY IN TIR \\ JOHNS HOPKINS UNIVIRSITY
}

\author{
ST. LOUIS \\ C. V. MOSBY COMPANY
}

1920 
<smiles>C1CCCC1</smiles> 


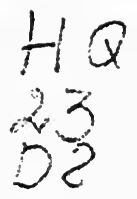

Copyright, 1920, By C. V. Mosby Coupany (All Rights Reserved)

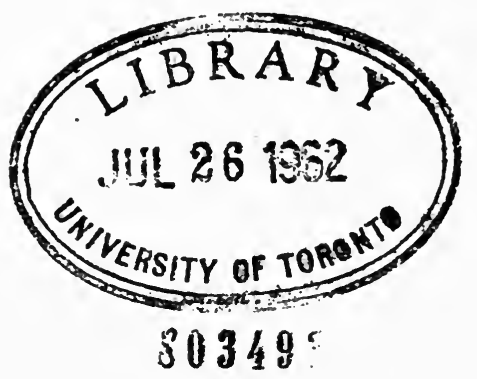

Press of

C. V. Mosby Company St. Lomis 


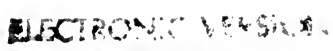

AYAUL, 10

พ5. $02+203$ 


\section{CONTENTS}

PART I

THE SIGNIFICANCE OF BEAUTY

Page

The Signimicance of Beauty................... 15

General Negative Characters.................. 18

Detamed Characters of Beauty................. 21

\section{PART II}

THE CONSERVATION OF BEAUTY

The Conservation of Beauty................. 55

Practical Steps in Conservation................ 65

INCEST AND INBREEDING.................... 70

Improvement in Sexdal Selection $\ldots \ldots \ldots \ldots \ldots \ldots \ldots \ldots, 75$

The Sfuection of Male Parents................ 89 



\section{FOREWORD}

From several persons who have read the manuscript of this essay, and from a larger number who have read the first part, I have received criticisms which are reducible to two main points: First, that I make the procreation of children the predominant ideal in marriage, minimizing companionship and other "spiritual" factors. Second, that although I call attention to various unsatisfactory conditions of sex relations, I have no practical reform program to propose.

Both of these points I admit without apology, and to both of them I wish to direct the readers' attention. I agree thoroughly with the position of the Church (as I understand that position), in declaring that the highest "spiritual" values of marriage result when it is most perfectly adaptated to its primary end. As a psychologist, I have the psychologist's prejudice, that ideals, intellectual analysis, and education are the fundamental forces of progress, and that laws, conventions, and customs serve to consolidate and make secure the gains achieved through these forces.

The first part of this essay consists, with some additions, of an address delivered in April, 1917, 
before the Association of Physical Directors of Women's Colleges, the Southern Society for Philosophy and Psychology, and the Faculty and Students of Randolph-Macon College, at Lynchburg, Va. ; and published in the Psychological Review for May, 1918.

K. D.

Baltimore, Md.

January 1, 1920. 


\section{$(n \cdot)^{n /}$ then \\ st. Levis 1920.}

\section{PERSONAL BEAUTY AND RACIAL BETTERMENT}

\section{PART I}

\section{THE SIGNIFICANCE OF BEAUTY}

Human beauty is something which is perennially celebrated in poetry, in song, in romance, and in the petrified conception of the sculptor, but " sins sivently considered in the cold analysis ur science. We are usually content to leave the topic to the artist and the lover, as one of the interesting and thrilling, but nonessential, matters of life. I wish to suggest a different conceptien of beaty: a conception-of-beauty as something which, whatever its importance for the individual, is for the race and for civilization of sueh-pro= found importance that no other fundamental consideration of human-welfare and-progress can be divorced fromit. I shall not touch upon the theme with the golden fingers of the artist, but with the unemotional digits of the psychologist. To some, without doubt, this procedure will seem as sacrilegious as the piercing of the anatomist's knife into the dead human form; but where the wel- 
fare and progress of humanity are at stake, even these brutal methods must be employed.

Beauty is a term of variable meaning; in fact there is a group of terms-handsome, pretty, attractive, charming, etc.-whose exact relationship is often discussed, and never settled. The way in which I use the term will not be acceptable to many persons, but one may reformulate my conclusions in his own way, using whatever terms he chooses, and the validity of the conclusions will not thereby be affected. I think it will be agreed, when I am through, that I have been discussing something rather definite under the name of beauty, and I hope further, that it will be concofed that, after all, what I have been discussing is that which in the common, and therefore vital, usage is actually designated by the term.

The familiar proverb tells us that "beauty is only skin deep," which nicely exemplifies the mendacity of proverbs; ugliness, it is true, is often skin deep, but beauty, never. Beauty, as I hope to be able to show, is-something whieh-depends upon the whole organism.

The conditions of beauty are in part negative, in part positive. That is to say, there are certain conditions which a person must satisfy in order to be classed as beautiful, yet which do not in themselves contribute to beauty; other conditions, such that their fulfillment constitutes beauty, or 
at least constitutes a certain element in the total beauty. Among the negative conditions are, for example, the lack of deformity. A hunchbacked woman or a baldheaded man is debarred by the deformity mentioned from being classed as beautiful, but the fact of having a straight back or of having hair on the head is-not-neoessarily-in itself a positive element of beauty. The negative condition is one which may be fulfilled, and yet the individual not be beautiful and not even have the corresponding detail of beauty. The positive conditions, on the other hand, are those which taken together in their fulfillment cause the person to be classed as beautiful. Some of these details may be present, and yet on account of other negative or positive factors, the total may not constitute beauty. Nevertheless we say that, in these details at least, a person does possess beauty.

This distinction between positive and negative elements, I am well aware, is not fundamental; it is at best a distinction of degree and convenience. But it is a convenience, for purposes of presentation at least, and we may make use of it while noting the fact that too great dependence upon it is fallacious. I shall consider first, therefore, the general negative conditions in order to clear the way for a treatment of the more detailed conditions, which, although involving both positive and 
negative elements, are better treated from the positive point of view.

I shall consider herein, primarily, only visible details. Qualities of voice, peculiarities of odor, tactual details, and so on, I shall notice only in so far as they are directly associated with visual characters. This is in accordance with the usual practice which makes beauty essentially a visible phenomenon and only secondarily a phenomenon which appeals to other senses.

\section{General Negative Characters}

1. Signs of race. There are certain negative details of stature, feature, color and movement and habits which are important because they indicate in the first instance a race or species of the human family against which, for reasons which may be instinctive or due to education, there is a prejudice. Facial proportions, for instance, which in themselves have no value, may yet indicate or suggest a branch of the human family against whom we entertain a certain bias. If we despise the Irish, an Irish cast of countenance cannot be beautiful to us. If we have an antipathy to the German or Russian or the French people, the type of face which suggests these people, even though there is no indication of actual blood of the race, is a factor making against beauty. The commonest instance of this 


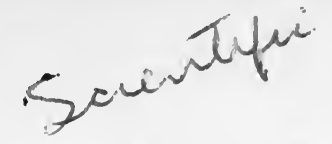

Racial Betterment

19

sort of negative condition is found in the hegroid. characters. Here, where the suggestion or indication is of an inferior race, the negative condition is especially important.

2. Signs of disease, deformity or weakness. Any indication, not merely of physical weakness, but even in some instances of mental or moral weakness or disease is of decided negative effect. One who looks like an imbecile or like a criminal is never beautiful; one who seems to have, or suggests, a deadly disease, is to that extent lacking in beauty. To a certain degree, these mental and moral standards are relative to the grade of the observer. A weak-minded person has not the objection to the weak-minded person of his own grade that the more normal ${ }^{*}$ person has, but I suspect that the person of low mental grade has a certain preference for the normal person. As regards disease and deformity, there is no question. A hunchbacked or an anemic man regards his characteristic as a decided bar to beauty.

3. Significant deviation from the average is a negative characteristic, even if the deviation cannot be classed as a "deformity." Dwarfs and giants, exceedingly thin and unusually broad individuals; those whose legs ${ }^{\circ}$ are too long for their bodies, or vice versa; those whose ears are misplaced, or whose hair is of an unearthly shade, are ruled out by their oddity, regardless of what these 
peculiarities signify. They may be good, clever, or admirable, but never beautiful.

These details are in part relative. Among certain African tribes, whose men are uniformly over seven feet tall, and as thin as a rail, a normal Anglo-Saxon is probably not beautiful. Among other African tribes, and certain islanders of the Pacific, a woman is not considered beautiful unless she reaches a degree and a distribution of fatness which makes her either repulsive or comical to European eyes. This relativity is, however, only superficial. The type whieh is

- thui

cutrue ti w th

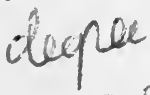

Becusts cle
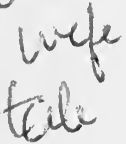

tettor

highest in value tends to approximate the European type, wherever the European type becomes known. All dark races prefer white skin, and it is a general rule that the female of the inferior race prefers the male of the superior race to the male of her own race, no matter how striking the difference. That the inferior male considers the superior female more beautiful than the female of his own race is indicated everywhere, and clearly demonstrated among the Turks.

Deviation from the common type, then, is a drawback only when it is not a deviation towards the acknowledged superior type of another race. The conservative dislike for the unusual in genferal is tempered by approval when the unusual is Gpcumenderlearly a mark of racial superiority.川 This will Nivit 
find its ready explanation when we consider the positive side of beauty.

4. Misplaced sex characters. A specific form of the abnormal, but one which is important enough to justify separation from the foregoing class, is the possession by individuals of one sex of characteristics properly belonging to the other. This is an invariable negative qualification in the eyes of healthy observers. The effeminate man and the masculine woman can be beautiful only to the moral pervert. The importance of this indication is very great, as we shall see later, and however little it may mean consciously to a given individual, the habit of reacting against it has been strongly developed in the human race.

Detamed Characters of Beauty

So much, in brief, for the general negative characters of beauty. We come now to more detailed characters, which have on the whole a positive value, although some of them have negative aspects as well.

1. Stature. From the point of view of the female, the male must be large, although not a giant, since, as we have seen, too great a deviation from the usual is a negative condition. I have at various times overheard women, who were discussing the relative handsomeness of two or several men, settle the point by such an observation as 


\section{Is thes}

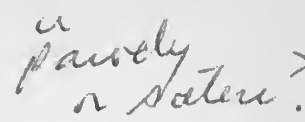

" $A$ is fully an inch taller than $B$. ." By carefully put questions I have succeeded in eliciting a considerable amount of information on this point without revealing the actual purpose of the interrogation. For example, if I inquire of a woman concerning the handsomeness of a man who has a general combination of desirable and undesirable characteristics, but who is a trifle below medium height, I very frequently obtain, in her first statement, a criticism of his stature, followed by a consideration of his other attributes; indicating that in her estimation size is of paramount importance. The determining factor is not, of course, mere height but height combined with lateral development not deviating markedly from the average proportion. The tall man of bean-pole build is not considered attractive. Yet, a positive element of height can outweigh a considerable element of disproportion, and a taller man, whose proportions are in themselves worse than those of a shorter man, is usually considered the handsomer.

This preference for stature undoubtedly harks back to more primitive times, when it was above all important that man should be a fighter and hunter; in order to secure food for his wife and children, and protect them against wild beasts and against the designs of other males. Especially was this important during the periods when the woman was pregnant, or nursing a child. It

\section{* see The Flinstores}


is highly probable that in ancient times the negative rule against abnormal size did not apply, since every increase in physical power, even if carried to the extreme of gigantic development, was a distinct advantage.

It is sometimes alleged that the woman's preference is not for the large man in an absolute sense, but for the man larger than herself; either because of a natural wish for a husband to whom she is inferior; to whom she can give a tribute of worship and deference; or else, that it has developed through the necessity of the greater strength on the part of the man in order that he might capture the woman, and carry her away from her parental habitat, to his own dwelling. Both of these suggestions are highly unplausible. Marriage by capture, although a good hypothesis for popular writers, probably never was at any time an institution of any more importance or actuality than it is at the present day. Psychologically, the theory is based on the assumption that woman is naturally opposed to the marital relation, which assumption is a merry jest, to say the least. Historically, there is no evidence for the theory of capture except as a limited and temporary phenomenon. As for the supposition of an unexplained instinct to prefer a dominant partner, I see no support for it, except in so far as the practical consideration I have advanced may itself 
lead to this preference as a secondary manifestation. It is true that there are women today who openly state that the mates they want are those who can completely dominate them; and that such potential masters are the only men who interest them. These cases (a number have been directly reported to me) are not all to be explained on the same basis, although the primary factor in every case is the admiration for the strong man. In some cases, the preference is distinctly a pathological development; in others, it is pretended by the woman as an explanation for the fact that men are not interested in her. In many cases, however, the preference is the expression of an arbitrary standard which is manifested usually in less egotistical ways. Where a scale of values is accepted, there is commonly a more or less explicit adoption of a minimal acceptable value; the stronger man is the more desirable; a man who measures up to a certain minimum will be acceptable. In most cases, the minimal standard adopted is the father, a brother, or some other impressive individual in real life or in fiction. In the case of a strongly egotistical woman, who sets a high value on her own potentialities, the standard is herself; the man less forceful than herself is below the minimum.

In this, I seem to be confusing physical strength with various sorts of power; perhaps I am; but, 
as I am trying to point out, the basis of power is muscular, and admiration for physical prowess still retains a primacy when it is a matter of the fundamental attraction of the woman to the man; and all $I$ am trying to establish at this point is that there is no primary desire of the woman for a man who is able to dominate her physically. On the contrary, the woman would prefer, if other considerations did not prevent, the mate whom she can control physically and in every other way, for the instinct to dominate is inherent in every normal human being.

Under present conditions, the preference of the large woman is accentuated, and that of the small woman reduced, by social factors, especially the fear of ridicule. The weakness of the small man is made conspicuous by the contrast with a giant wife; compared, on the other hand, with a diminutive wife, his inefficiency is less emphasized.

From the point of view of the male, the question of stature is less simple. There seems to be no general preference for small women or for large women; but a truly relative preference for smaller women. Of course, I am well aware that there is a wide range of individual preferences, not all of which are explicable from available data; but I am speaking of generalities, which are certainly discoverable, in spite of individual differences. This general relative preference in the 
matter of stature is complicated by the curious double preference of the male, which is so strikingly demonstrated by theatrical studies, and to which I shall make brief reference later.

The primitive reason which leads woman to prefer a large man has no correspondence in the necessities of the male. The male has not the need for protection at certain periods which the woman has. While the addition of a husky female to the savage's fighting force would seem to be a prime advantage, the advantage is largely lost because at the precise times when the aggressive resources of the family are most fully needed, the woman is not in condition to exert her strength, without serious injury to herself. The physical strength of the woman is not to be counted on, and hence the stronger woman is not a greater asset to the family, and hence no more desirable.

It is true, there have been and still are, races in which the physical strength of the women has been counted on, especially for agricultural duties (e.g., the American Indians); and among them, possibly (I am not certain on this point), stature has been a mark of beauty. But where female strength is counted on, it is necessarily utilized at times when grave damage is done to the woman, and those races which have counted on it have gone down. The races which have early developed chivalry, as we may well desig- 
nate the protective attitude, are the races which have developed civilization, and which must continue to dominate the world unless civilization is to be abandoned, and the human race plunged downward into bestial degeneracy.

Stature, therefore, except in so far as it may be involved indirectly in some of the factors which I shall yet consider, is not and cannot be a mark of female beauty in a civilized race. On the other hand, by this very fact, the preference for a partner whom he can dominate is allowed full sway in the male. The woman would have the same preference, as I pointed out a moment ago, were it not checked by other factors.

I may digress for a moment, to remind you that in a family one person must control. This is not a theory, but an empirical fact against which argument is futile. Economic conditions which are as yet but dreamed of, especially those conditions which result from the greater and greater use of machinery, may in future change this; but it was the law of the primitive family, and even yet we have not reached a stage of civilization in which a joint legislative authority is possible. In the past it has been the male who has controlled, but that may be changed in the future. It is true that Bachofen and others have tried to establish the doctrine of the matriarchiate (the rule of women) as the primitive family system, but the confusion 
on which this theory was based has been readily exposed. Never in the history of the globe did woman have the political and social power she holds today, and suffrage cannot increase it.

2. Bodily proportions. In modern civilization there has grown up an immodesty which was lacking in more ancient cultures. We are ashamed of our bodies. Whether the practice of concealing the body is the cause of our uncleanness of mind, or whether our obscenity is rather the cause of the concealment, is a debated question. $b$ Whatever may be my general estimate of the Japanese, I cannot but admire their wonderful cleanness of mind, which makes for them clothing a detail which has no bearing on modesty.

Among the Greeks, who, as you know, were in many respects more pure-minded than we are, bodily conformation was an important detail in beauty- And, in fact, it is today amongst us, both in a shame-faced way in daily life, and more creditably when we throw off our prudishness in the presence of plastic and pictorial art, and in the theater. We are skirting here a vital and pressing problem of the present moment, on which I should like to take the time to make you face some problems we all tend to ignore, but I must not digress further.

Our standards of bodily development are still, in the main, Greek. There are certain proportions

* Ihate the little slope heads... 
which are judged both by the artist and the layman to be the ideal of beauty. In this we are of course swayed largely by the limitations of our education, which on these matters is artificial; probably there would be a greater difference in racial ideals, if conditions were more natural.

The simplest explanation for the accepted ideal of form would be that it is the average form of the healthy individual. This explanation, I think, is not supportable. Among the Greeks and Romans, for example, the ideal ankle, for a woman at least, was a small ankle, not a medium-sized one. Among us, a small foot has been desirable; footfetishism]. so much so that women have been compelled to wear shoes which, by raising the heel several inches, make the ground-base of the shoe about two thirds the real length of the foot.n This procedure makes the foot seem shorter, or at least it did until the recent shortening of the skirt brought the artifice out where it cannot be overlooked. One of the most important and desirable effects of the permanent adoption of sensible clothing by women will be the allowing of the foot to retain its natural form. "Of body-form, which is by rights the fundamental consideration in beauty, I shall say nothing further, because our standards are so obscure. The subject is in need of thorough investigation by the methods of
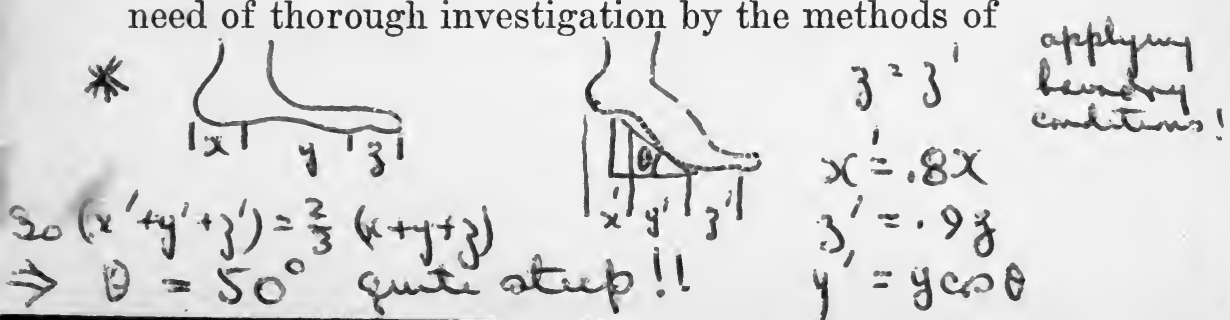
comparative anatomy, and above all, of social psychology, and engineering analysis. 3. The Features. Whatever the cause of our concealment of the body, it has led to an emphasis on the anatomical details of the face which could not be found in more primitive times. Leaving out of consideration the general shape of the face and head, which are probably important mainly as racial signs, we may consider briefly the ehin, the-nose, the eyes and the ears.

That there is a preference on the part of both sexes, and in the consideration of both sexes, for a well-developed chin, is a matter of common knowledge. The reason for this preference is less evident, and in fact I can here indicate only a strong probability. Racial factors are involved, of course, but there seems to be a more general foundation which is vaguely involved in the commonplace statement, that the possession of a chin is one of the conspicuous points which differentiate man from the beasts. This is obviously true; the vital question is: What are the direct consequences of this structural peculiarity? This question can be answered by reference to comparative anatomy and to the psychology of the thought processes. The projecting chin gives room in the mouth cavity for the human tongue, which is strikingly different from the brute tongue. The tongue of the lower animal is a long thin strip of 
muscle; the tongue of homo sapiens is a thick muscular mass. A somewhat exaggerated comparison is to a leather strap, in one case, and a frog seated in the mouth in the other case. We have now advanced the question one step farther, to ask what may be the advantage, if any, in the form of the human tongue. cunnilingus of course

The animal tongue is certainly just as well adapted to the purposes of obtaining and preparing food, as the human. In some cases, it is even more efficient. But the human tongue is an important instrument in the production of the most human of all attributes, language. Language is not merely the means of communicating thought; it is, as philologists have long known, and as psychologists have been forced somewhat unwillingly to admit, the principal means of thinking. While it is possible to think without language, languageless thought is primitive and inefficient in the complex conditions of civilization, and it is by no means an exaggeration to say that the development of language is a large part of the development of thought.

Of course, it is not to be said that in any specific case a large tongue is an index of efficient thinking, or that a relatively smaller chin indicates necessarily a relatively smaller tongue, or that the converse of either of these propositions is true. But on the whole, the development of the ehin 
is concomitant with the development of thought, and henee, in races or large groups, an index of mental development. It is worthy of note here, that the marks of beauty will be found throughout to be these generalized characters, which in specific cases may not be associated with the fundamental factors which have made them important.

The nose and the mouth are beauty-eharacters which are probably more exclusively racial in their significance than the chin. The broad flat nose and the thick wide lips are often repulsive because they suggest the African, if for no other reason. But I suspect that the thick lips are-atso a-defect because-they are in themselves a hindrance to efficient speeeh, and more vitally-because they connote an inefficient formation of the mouth, palate and glottis: Yet it is necessary here again to point out that any of these details may be faulty in a particular case, and yet the others be so well adapted that they more than compensate; and that there may be in many cases language, efficient for thinking, but inefficient for communication. Here as everywhere, our beauty judgments are based on conditions which are general, and to which there are many sharp exceptions.

As regards the teeth, we are in no serious doubt. The beautiful teeth are the sound, regular weapons, which by their form and color give unmis- 
takable evidence of being efficient for chewing as well as for primitive methods of warfare.

While the practical indications of the mouth are important, as I have pointed out, we should by no means overlook the probability of a sexual significance to the evaluation of which the consideration of other beauty characters will rapidly drive us. I need not remind you that popular theory as passed from mouth to mouth and as embodied in literature of all ages, considers both the mouth and the nose as practical indexes of the sex-organs; I should like to express the opinion that popular theory, even popular superstition, is the smoke which always indicates some fire. This particular popular belief is one on which it seems to me it wonld be worth while for directors of physical unlture to make statistical observations.

I need not point out the sexual function of the olfactory organ in the nose of the lower animal; buc I ought to warn you against the fallacious opinion that in the human animal the nose has universally lost that function. On the contrary, in a large proportion of the species that function has become more complex. I may add also, that in addition to the significant fact that the membrane lining a large part of the nasal cavities is erectile tissue, there are definite psychological observations, (none published, I believe), 
which throw experimental light on the sexual relations of the nose.

That both the eyes and ears are beauty marks, and that, in the female especially, they have been selected for especial emphasis by lovers and poets, you are well aware. Both love and poetizing, as most of us well know from our own experience, are conditions of irresponsibility in which the fundamental instincts and habits have large sway; and the first condition usually brings on the second; accordingly the beauty-points which fix the attention of poets demand our attention. But there is little to offer at present in the way of analysis of these. Aside from the indication of physical condition which the eyes afford (and every physician makes use of these indications), the importance of the eye is probably largely racial. The blue or the black, the large or the small, are not in themselves of moment, but they indicate-stocks from which we expect certain other charaeters, mental and physical. The same general consideration is probably involved in ear preferences. This is however by no means the whole story. Anyone who has studied the religious and art symbolism of primitive peoples, and of people not so primitive (I do not refer to the crude and artificial studies of the Frendians) cannot help but see very definite reasons for the fascination of the eye and ear, rea-

sons which are more appropriately discussed 
amongst psychologists than before a general audience.

Before passing on to the next topic, I wish to protect myself from possible misapprehension by disclaiming any taint of phrenology or blackfordism in the preceding discussion. The significance of cranial and facial characters must be worked out on the lines of physiology and genetics; psychologists have no sympathy with the various systems of so-called character analysis which attempt to decide from a casual examination of an individual what his intellectual and moral peculiarities are in detail.

4. Hair The hair which adorns the human body (or disfigures it, as the case may be), is of two sorts, in regard to its physiological conditions and significance, as well as to its regional distribution. The hair of the head, or pate-hair, is the one sort, and the body-hair, including the face-hair, is the other.

The conditions which govern the growth of the pate-hair are not definitely known, but are probably connected with bodily changes which have other important effects. That is to say, the stimulation of the growth of the hair, or the failure of its vitality, are probably due to changes in the internal secretions (hormones) of the organism, although it is not known which of the secretions are the important ones in this connection. It is 
probable that another effect of the internal changes which produce baldness is a lessening of the resistance of the organism, so that the baldheaded man cannot stand the muscular exertion or the nervous strain of which the hairy-headed man is capable. At any rate, baldness is a fatal bar to beauty, both in the malè and the 1 iemale, although to many persons (men especially) an individual of the opposite sex whose pate-hair is exceptionally abundant is repulsive.* Another indication of the dependence of the pate-hair on metabolism in other regions is found in the apparent connection between hair and temperament. It is difficult to conceive of a baldheaded musical genius or artist;? although even to the rups mpliè here, exceptions do occur. Temperament, and all emotional factors, as we now know, depend largely on the bodily metabolism, especially on the functions of the internally secreting glands. The quantitative hair character, therefore, may in all probability be reduced to an indication of physical vigor; and physical vigor is far more important, as a beauty asset, than mental ability. Whether the popular belief that the mental ability of a child is in the inverse proportion to the growth of his hair, has any foundation, and whether a similar rule holds for

\footnotetext{
*'The attractiveness of a thick head of hair on a man, from a woman's point of view, is largely tactual. A number of women have analysed this as depending on the pleasure they would derive from running their fingers through the hair. This point is substantiated by actual behavior.
} 
adults, I shall not discuss, as I might be accused of being prejudiced. You? NEVER!!!

The other details of the pate-hair character: fineness or coarseness, straightness or kinkiness, color and contour of distribution, are largely important as indicators of race or stock; yet fineness, has a direct sex value in its greater pleasingness to touch. It may also be true that color has a direct value; that the masculine preference for red-haired women which is so frequent, and of which the Elizabethan and pre-Elizabethan erotic writings are so full, is not due solely to the association of the hair color with the ardent temperament which without doubt was a characteristic of the red-haired stocks; but is in part at least due to the direct effect of the visual stimulation.

All parts of the body except the palms of the hands and the soles of the feet, and certain other small areas, are covered with fine hair, which in the pre-adolescent person are usually so fine and so colorless that they are hardly noticeable. With the beginning of puberty, the axillary hair (the hair of the arm pits), and the hair of the pubic region in both sexes begins to develop, increasing in diameter as well as in length and in pigmentation. In the male also, but slightly later, the face hair undergoes similar development, and still later the hair on the chest, abdomen, and limbs of the male develops in manners which differ greatly 
in different individuals. In the typical, functionand
nowenen -
swave lest
xheir ally perfect woman, on the other hand, the bodyhair, except in the restricted regions mentioned, remains as fine and as colorless as in the child. This hair development is not associated with sexual ripening in a chance way, but is controlled by the fundamental sex glands. These glands not only produce the germ cells (the egg and the spermatozoön) whose union creates the life of a new individual; they secrete also, into the blood stream, hormones, $i$. e., substances which profoundly. influence the growth of various parts of the organism. The internal secretions of the male glands produce those changes in the vocal organs which are indicated by the voice becoming heavier and lower; stimulate the growth of the bodyhair in the manner above indicated; and undoubtedly promote those structural and functional changes which are evidenced in the tendencies of feeling and action distinctive of the male. If the glands are removed in infancy, these changes do not occur. The secretions of the ovaries, on the other hand, seem to inhibit the growth of bodyhair, to accelerate those structural changes in the muscles, glands and skeleton which differentiate the woman from the man, and promote those functional modifications which make the feelings and emotions of each sex a sealed book to the other.

It may be said of the important races of man- 
kind that, in general, the development of the faceand body-hair in the male, and the absence thereof in the female (except in the three limited areas), are alike an indication of fitness for parenthood. The decline of the sex function in old age is usually marked by significant changes in these deGARBAGE tails. There are of course many apparently anomalous cases, some of which may be explained by glandular details into which the limitations of time forbid us to go; but in spite of these cases, the social verdict is uniform. The hairlessness of the female face and body, and the hairiness of the male face (or the evidence that the hair grows, although shaved off) are important elements of beauty. The male body-hair has little value, because of its irregularity, and the fact of its usual concealment.

There are a number of interesting problems which arise in connection with the body-hair. Theoretically, the pubic hair should be as beautiful, at least, as the pate-hair; yet the Greeks, who set our official standards, did not think so. ${ }^{*}$ As to axillary hair, there is lacking information as to its indicatory value. It is an interesting observation, however, and one of no little psychological importance that in recent years when the morbid

*I am informed by Professor Robinson that the Greek women uniformly removed the pubic hair (usually by singeing), probably on account of pediculi. That the esthetic standard is a result of this practice is plausible. 
shame of the body was somewhat lessened, and young women began to expose their arm pits freely in the ball room and theater, some removed the axillary hair, and others did not. A little later, the practice of removing the hair became practically universal, and now the hair is seldom seen. Probably the conflict of opinion in these matters is really between the man's judgment of beauty and the woman's. But we must pass over these details, and hurry on with our main problem.

It is evident now that whether there are other considerations or not, the most-important element in the beauty of any individual-is the evidence of her (or his) fitness for the function of procreating healthy ehildren of the highest type of efficiency, aceording to the standards of the race; and ability to protect these children. The positive beauty charaeters-we have already examined are clearly such marks of ability to perpetuate the species-in the finest and noblest way, and the characters we shall now consider strengthen the interpretation.

5. Fat. Here again there are racial differences, but amongst the European races, no racial indications. We may leave out of consideration the Africans and the -South Sea Islanders, with their criteria of beauty-fat which seem so odd to us, but which are quite intelligible when viewed in the light of racial characters, and consider Western conditions and standards. 
A certain amount of fatty tissue is normal, and is essential for the health of the individual. Fat constitutes a store of reserve material, which may be drawn on in time of unusual need; and without it endurance is limited. This reserve store is probably not so important at present as it was in primitive times, when man lived in a hand-tomouth way, uncertain today what the food supply would be day after tomorrow. On the other hand, beyond a certain amount, fat is an encumbrance, impeding the operation of many organs, and thus limiting the efficiency of the individual, and also is in itself a symptom of faulty organic functioning of some kind. We are not surprised therefore to find that beauty demands just the-right degree of leanness; just the degree which is found in the most vigorous individual.

The standards are somewhat different for the two sexes, because the anatomical conditions and physiological necessities are different. In the female, especially in the young female, there is a special layer of fatty tissue underlying the skin, which is absent in the male. This gives her the roundness and softness of outline which is essential to the perfection of feminine beauty, and also prevents her from feeling the cold so much as the male does. Possibly also it explains why she swims more easily. (It is a fact that women are as a class far better swimmers; this has been ascribed 
to the better development of the legs, but this reason is hardly sufficient, since it has been shown that leg action is the least important factor in swimming.)

The softness and-roundness-of-contour of the female is beautiful, because it is the mark of physieal fitness. The fatty layer is supposed to be an extra reserve supply of food material, laid up against the heavy demands which are made by child-bearing, and in still another way protects her in that supreme process, of whose splendid fruition beauty is the glorious blossom. When age withers, through the absorption of the adipose tissue, primary beauty is on the decline, and unless it be replaced by the secondary beauty appropriate to advancing years, the drama of life becomes a tragedy. And indeed, the great fact that we all must face at some time, that the strength and vigor of our prime is past, and that the time when the almond tree shall flourish and the grasshopper become a burden advances upon us, is usually announced to a woman in the. discovery of wrinkles due to the slipping from her of her subcutaneous robe of office.

6. Complexion. The tint of the skin, of course, is largely a racial indication, but in certain respects, the tint, as wellas the texture, is-an-index of health and vigor. The standard of beauty in complexion, whether light or dark, is that which 
goes with the full bloom of sexual vigor, when the human organism is at its perfect development for the perpetuation of the species. This is so obvious that it would be superfluous to discuss it further.

7. Muscular tonicity. The voluntary muscles of the body, $i$. e., the muscles of the face, scalp, trunk, arms and legs, are kept in a condition of tomus, by nerve currents constantly supplied to them by the motor nerves. Tonus is a state of partial contraction, which constitutes the readiness for action of the muscle. If the motor nerve trunk which supplies any voluntary muscle be severed, the muscle at once becomes flabby. The tonus does not depend entirely on the nerves which stimulate the muscle. In order to be stimulated, the muscle must be in the appropriate chemical condition to receive the stimulus, and this chemical condition is dependent not only on the general metabolic conditions of nutrition, fatigue and rest, but also on the specific actions of hormones produced by several of the internally secreting glands, notably the adrenalin produced by the adrenal glands.

In case of injury or disease affecting certain parts of the nervous system, eertain muscles become flabby. In case of general flabbiness, it is of course not evident immediately whether the primary defect is in the nervous system, or in the metabolism of the body. In any case, flabbi- 
ness, local or general, is a symptom of inefficiency in bodily functioning, and although under modern conditions the flabby individual may be able to make his living at his particular restricted occupation, flabbiness unfits him for parenthood now, just as much as it did in the stone age. We can't breed husky children from flabby parents.

The flabbiness which is due not to a specifie injury or disease, but to-insufficient vitality, is first shown by the muscles of the face. That is to say, it is first shown to the casual observer; a medical examination would probably find it in other muscles first. It is not entirely due to the concealing of the body that the facial muscles have become known as the muscles of expression. Failures of tonicity in these muscles are conspicuous; the-sagging eyelids or corners of the mouth, or cheek muscles and other modifications which are readily observed but described with difficulty, are-common traits which are fatal to beauty. In fact I do not hesitate to say that, assuming the conformation of the features, and the complexion, to be not actually objectionable (that is, assuming the bare negative conditions), beauty, in so far as it is facial, depends on the proper tonicity of the museles.

The activity of the facial muscles expresses the mental and still more the emotional activity of the individual in a plain way. Vivacity and dullness, 
cheerfulness and gloom, benevolence and rancor, interest and ennui, and a multitude of other conditions are written in the facial movements for the runner to read. Boldness, modesty, candor, deceit, innocence, guilt, and other moral qualities may be expressed in the contractions of the muscles surrounding the eyes. But in repose, these muscles are expressive in another, and perhaps more important way, for they show-the potentialities of the individual; what he is capable of, in so far as the capability depends on the functioning of the nervous system and the endocrine glands. A person may be attractive, while the face is in action, because the action indicates a desirable type of mental or moral activity going on; but she is not to be judged beautiful in face, unless the face in repose expresses desirable potentialities. A common form of expression is "she -is-beautiful only when she smiles:" a better statement would be "she is attractive when she smiles, but she is not beautiful."

8. Poise. The consideration of the expression of mental and emotional qualifications leads us over into the general problem of the participation of mental traits in personal beauty. There is no doubt of the value, to the race as well as to the individual, of a high degree of mental development, provided always that the development does not so destroy the physical balance that the in- 
dividual's chance of survival is impaired. Development in some individuals, by special environment and training, of mental capacity beyond the point of balance, is doubtless of value to the social group of which they are members, but the increase in stock which tends to general overmentalization is a dangerous factor.

The underdevelopment of mental capacity, even at levels far above feeble-mindedness and other obvious mental defects, is a form of inefficiency as positive as the overdevelopment. We can conceive of a world peopled by a race of men and women of splendid physique, from which the common grades of undesirables have been eliminated: a world in which each individual seems admirably constituted for mating and creating children after his-kind. Great content and happiness, and joy in the appreciation of the beauty of their mates, might obtain among this people. Nature too would-smile on the race which had so far eomplied with her conditions. But if this race could attain no further than eminence-in-the traits-wehave previously considered, it would be a failure. As a matter of fact, a nation on this plan would have a low chance of survival in conflict and eompetition with nations which had gone beyond it into-a richer mental and spiritual flower and fruition.

If-it were possible to apply comprehensive and 
aceurate-mental-tests to candidates for mating, and so to seleot in accordance with adequate mental standards, racial betterment might be attained along this line: but we have no eriteria which are capable of such application, and cannot foresee the time when they may be available. The important question, therefore, is-whether there is an element in beauty itself which serves as an index of mental and spiritual potentiatity: or whether our-selection is indeed blind in this respect.

The mental life of the individual: the processes which directly involve consciousness: depend, as we now know, on the integration of the nervous system, and not on the specific activity of certain cell-groups in the brain. The nervous system is made up of myriads of nerve cells-neurons-, each one a distinct individual. These neurons form chains of communication from every sense organ to every muscle and gland. Many of these lines of communication may, at certain moments, operate in relative independence of one another. The lines which control the merely "physiological" processes usually possess a relative independence. Conscious reactions, on the other hand, are reactions of a large part, if not of the whole of, the organism: reactions in which the "nervous discharge" over a vast network of routes, is integrated, or welded, for the moment into a single function of the complex system. 
This integration is probably never perfect, but reaches a high degree in the most efficient functioning. When the integration falls below a somewhat indefinite low level the failure gives rise to the symptoms of "functional" nervous disease.

The individual who is capable of a high level of integration under-specific conditions and training, is not necessarily able to maintain an effcient level under the various conditions which must be faced in daily life. The distinguished mathematician, or lawyer, or "specialist" of any sort, may show, along with his particular effciency, some of the symptoms of mental disease, or be inefficient in many circumstances not involved in the immediate practice of his specialty. These-individuals,-therefore, do not represent the stock from which the race should be bred.* More desirable, is a more generally integrated stock, to be improved in its general integrative ability as much as possible, and from which individuals of specific integrative type-specialists in the several lines of mental effort-may be developed as offshoots.

Sound integrative function: the foundation of sound mental life: is practically reeognizable, and is an actual element in human beauty as it is estimated in eivilized societies - We call the

\footnotetext{
*These conditions are practically satisfied by the failure of geniuses to produce offspring. Our Shakespeares, Newtons, and Washingtons have left few descendants.
} 
evidence of this eapacity poise, and read it in the individual's activities all the way from such commonplace processes as walking and talking, to the most complicated reactions under social conditions. Proper muscular tonicity is of course a necessary condition for poise, although it is but part of the total. In all its details, however, poise takes us over from mere anatomy to action.

Without poise, beauty is the beauty of the marble statue and the painted canvas. In the competition for mates, poise undoubtedly plays a very large and entirely worthy rôle. Singularly enough, in one of the institutions in which poise should always be considered essential: in the stage beauty-show: poise has in some recent instances been very much neglected, with results which strikingly demonstrate the importance of this attribute. I shall refer to this further on.

Although our survey is far from complete, it has proceeded far enough to show us clearly in what beauty consists. It is the sign and the expression of the potentiality of the individual; not what he has done or is doing, but what he is capable of doing; not what he is capable of doing for his own interests, but what he is capable of doing for the species. Put in the plainest of terms, the most beautiful woman, the handsomest man, are the persons we would choose to be coparents of

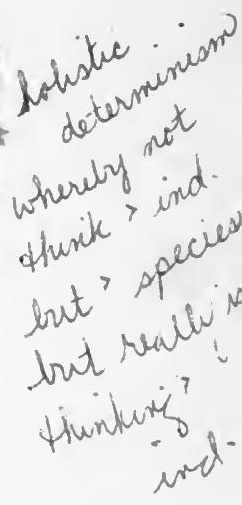


our children, if we considered nothing but the highest mental and physical welfare of these children.

The-reasons-for-the actual matrimonial ehoices of society are complex, beauty being only a minor consideration. For the student of social psychology the investigation of the other factors is of absorbing interest, but here I may say merely that the predominance of these factors is a calamity. As a physiological psychologist, I must repeat what the poets have sung: the glorification of beauty and its exaltation as the primary ideal, which ought to reign in human life. Of all the divinities in the Greek pantheon, the most glorious are not Zeus and Hera, not Ares and his Aphrodite Pandemus, but Apollo and Aphrodite Urania, the life-giving queen of heaven.

It will be noticed that I have omitted moral qualities from the composition of the beautiful individual and have ignored the physical characters which connote these qualities. In this I have been consistent, and am in perfect agreement with common usage. Beauty may be proud, cruel, deceitful, immoral, wicked; and yet it may still be beauty. Cleopatra was capable of almost any crime you can think of, and Thaïs was no modest violet; but history tells us that they were of wonderful beauty. "Handsome is as handsome does" is true only in a qualified way. 
How, then, can we elevate beauty to the rank we give it, since it satisfies our social demands only in part, and in what many consider the less essential part? We must do so, because it is the foundation on which truth and holiness are built. Only the race which is physically and mentally fit can survive and flourish long enough to develop and put in practice moral ideals. The problem after all is not one of choice between two ideals, but of having such regard for the primary ideal that it may help us to the attainment of ultimate ideals. In a more specific and limited way the problem of right and might exemplifies the guiding principle, which is therein not a choice between right and might, but the bringing of might into the service of right.

So much for the salient characters of beauty in the meager treatment I can give them here. I might now mention two other points which possibly will set off more clearly the conception I am trying to express.

Although beauty, in the primary and fundamental sense of the term, is prospective, we sometimes use the word retrospectively, as when we speak of a beautiful old lady or a handsome old man, indicating thereby a person who evidences the past possession of characters valuable to the race. In a certain sense, the retrospective characters of beauty are the same as those which con- 
stitute beauty proper; but nevertheless there is a tendency to admit, or rather demand, especially of women, moral characters not demanded in the case of primary beauty. While the handsome old man is, rather strictly, the man who still retains in some degree the marks of positive beauty (the marks having a retrospective signifieance), the beautiful old woman is she who, retaining the retrospective characters; also gives evidence of graces and temperamental qualities which are possibly more the result of environment than of constitution, and which in the younger woman are set off from beauty as "sweetness."

This admission of retrospective personal values is one feature of the consideration which civilization has given to the aged, $i$. e., to the individual no longer potential for the race. This consideration, perhaps, has not increased since patriarchal times, but it is an advance over the attitude of still more primitive races amongst whom the individual who is no longer useful as a warrior or a parent is ignored or eliminated.

Finally, I must refer to the popular distinetion between prettiness-and beauty; a distinction which at least as it applies to women rests on solid psychobiological grounds, and which offers abundant opportunity for psychological research, having practical application to some of the pressing social problems. 
The pretty woman is she who possesses certain of the characters of beauty, but in-such combination that they are not an indication of the general potentiality requisite for beauty. The characters of prettiness are the characters of beauty which promise least for the stamina of the race. Without extensive analysis of these signs the distinction may be summed up by saying that a pretty woman might be the man's choice for a mate, but not, other considerations being subordinated, for the mother of his children.

There is doubtless a valid distinction in types of men, corresponding to the distinction between "beautiful" and "pretty" women, but it is practically unimportant because of the singleness of woman's judgment. Men, however,-are as a sex strongly interested in pretty women as well-as in beautiful ones.

On this point, certain observations on theatrical performances, especially musical comedies, are illuminating. Details are too lengthy to introduce here; but in brief, the types represented by the show girl and the dancers are necessary to give the chorus (the foundation of the show) the widest appeal to the males. This is a fact of practical importance to producers, and I have found no difficulty in obtaining abundant introspective confirmation from men of all classes. Some men are interested almost exclusively in the type of show 
girls who evidently would be splendid mothers; others are primarily interested in the types who are attractive in a more immediately sexual way. The great majority of men, however, are strongly interested in both types, and have little difficulty in identifying the grounds of the two interests. The stage, I may remark, is to social psychology what the laboratory is to individual psychology, furnishing the possibility of experimental tests, especially in the domain of the problems of the family, to which the topic of this paper properly pertains.

I have sketched, in the preceding discussion, the line of observation and reasoning which supports my opening statement that beauty is something vitally important for the human-race. It is unnecessary that I should fill in this outline with more detail, because, having once become impressed with the scheme, whether favorably or adversely, the details will be filled in from your daily experience, and will in the end leave no doubts as to the truth of the matter. It is therefore the business of the social psychologist to lead the way from this point to the next, and practical one, the conservation of beauty. 


\section{PART II}

\section{THE CONSERVATION OF BEAUTY}

Human beauty, we have pointed out, is a sign of fitness for parenthood:-fitness to propagate children who shall be, in high degree, able to hold their own in the mental and physical struggle with nature and with their human competitors. It is the sign which is intuitively reeognized by the race and upon which the process of sexual selection is based. It therefore is nothing superficial: it is the external appearance of the germinal potentiality which is the most important of all things for society.

When we say that this-sign is intuitively reeognized, we do not mean that it has any mystic properties: we mean that it is-a-sign which is accepted and acted upon, without-induction or inferenee, or reasoned-process: recognized in the visual details of form and coloration and graceful movement, in the audible details of voice, and the tactually felt smoothness of skin and firmness of muscle and glossiness of hair. Concerning the processes of development through which this recognition may have passed, and the conjectural mechanism through which it has come about, we need not 
speculate. That it is a fact, is the point upon which our emphasis should be placed.

In the absence of more scientific tests of the racial potentiality of the individual, beauty must be used as our guide-beauty as we have described it in the preceding chapter. And, since the-betterment of the race should be evidenced by an increase in that which is the sign of desirable qualities, the problem of racial betterment is the problem of conserving beauty, and eliminating ugliness, that beauty may more and more predominate; and the race become more and more fit, instead of declining under the influence of those factors in civilization which inhibit sexual selection and natural-selection.

At the present time, we have no right to assume that any strain of the human race can be improved. Transmission of acquired characters may be possible, but the burden of proof is upon those who maintain that hypothesis. Nevertheless, we know that improvement in mixed stocks can be secured by the selection of the more fit, and the elimination of the less fit. In stock-breeding, we-propagate from those individuals which show in highest obtainable degree the qualities we desire, and by so doing we improve the breed. We have reason to believe therefore that in the much mixed human races, by increasing the breeding of the more beautiful individuals, and deereas- 
ing the breeding of the less fit, the level of the race may be raised, since the better strains will thus gain a greater and greater predominance over the weaker. Even if it be possible to gradually improve the poorer strains themselves (which-we have said above is not probable), the sure and far more rapid method of improvement is the elimination of these weaker strains, and the multiplication of the better.

In two ways the progress of civilization has obstructed the propagation of the fittest, and facilitated the multiplication of the unfit. The first way is by the development of humanitarianism, and the development also of efficacious tools for its use: surgery, pharmacology, and prophylaxis, with large funds a ' personnel to apply them. By the active influence of humanitarianism, the less resistant, less Jis le have been given a greater ratio of survival and with the increase in survival has gone $\mathrm{a}_{i}$ increase in propagation.

I am not unappreciative of the benefits of humanitarianism; it is the real glory of civilization, and we would be Huns if we did not realize it. It is true that many of the individuals whom science and philanthropy snatch from untimely ends, although individually weaklings, are weaklings by economic accident and germ infection, but really belong to desirable stocks and are capable of propagating desirable progeny. Moreover, the es- 
sence of civilization is the fact that it places a yalue on the individual where nature places value only on the species. The true type of natural valuation is illustrated by the bees, the male of which dies in the act of copulation, the female is discarded as soon as she ceases to produce eggs copiously, and the neuters are mere machines to care for the eggs and feed the queen and larvæ. That this sort of social organization is not good for man, however well it suits the bees, the Germans have impressively demonstrated. Although civilization evaluates individuals as such, regardless of the sort of offspring they produce, it dares not nullify the laws of nature beyond a certain limit, or it would commit suicide. The obvious compromise is to preserve the-individual, whether virile or weakling, but to prevent the weakling from reproducing. Thus both humanitarianism and racial needs are served.

Perhaps there are-limits beyond which the preservation of the individual is undesirable- It seems not onty useless but-dangerous to preserve the incurably insane and the lower grades of feebleminded, even when we consider the case from the individualistic point of view. When we estimate what the personal labor put into asylums and into institutions for feeble-minded, might accomplish if expended in the poorer districts of our cities in teaching the children who will be the parents 
of a large fraction of the next generation of citizens, how to work and play, it seems a pity that we cannot asphyxiate the hopelessly insane and he il! feeble-minded as kindly as we do stray dogs and cats. Such a course of procedure, however, is impracticable, for the reasons assigned below against legalized sterilization.

The-second way in which eivilization interferes with the conservation of the desirable human qualities, is in-setting sexual values which confliet-with those-of-beauty, and-which obscure or override them.

The naturat desire for children is-inhibited by other desires of various sorts: desires which in many cases are good in themselves, but whieh are so puffed up by civilization that many couples who are personally qualified, legally authorized, and economically able, to create children, produce none or too few. On account of these social values which civilization creates, many who are excellently qualified for parenthood do not even marry.

On the other hand, the social values which are purchasable by wealth and which again, are in many cases commendable, often obscure personal undesirability; and men and women who, in a more natural order of things would not be counted beautiful; nor considered desirable coparents, are songht after and married. Fortunately, it frequently happens that the inhibitory process we 
have just mentioned; the checking of the desire for children by conflicting social values; enters into a great many of these mammonistic marriages and tends to neutralize their evil results. The harm of mismating is not completely destroyed by childlessness, however, for although the positive damage-the procreation by the unfit parentmay thus be prevented, the loss due to the nonprocreation by the fit mate in such a union is not made up.

Features of civilization which are in themselves good may, as indicated above, work serious harm in society which has not yet completely adjusted itself to these features. Certain benefits, on the other hand may accrue to society from features which are in themselves malignant, even though the evil wrought by these features is enormously in excess of the incidental benefits. Prostitution is one of these sinister features, which, it is probable, has conferred slight benefits on society, and has also contributed to social modifications whose value is open to serious question.

Prostitution is a social institution developed with civilization as a result of social maladjustment: maladjustment of the various other institutions which develop by irregular growth. Although no longer accepted as a necessity, it resists all attempts to eliminate it based on the assumption that it is a primary institution, instead 
of what it really is: namely, a derivative. Like all symptoms, it is to be treated as a symptom, and removed by removing the causes. Neither homeopathic nor allopathic measures have had permanent remedial effect upon it. Yet, like all symptomatic phenomena, it has direct consequences, flowing from it rather than from its causes, and these consequences are probably both good and evil.

Prostitution has undoubtedly had some effect, and possibly a large effect, in checking the increase, if not in producing the decrease, of certain individual qualities which are deemed undesirable, either from the personal or the social point of view.

In its commonest form, prostitution is a means of limiting the sexual freedom of women, while extending the largest freedom to men compatible with such restriction upon the female. It provides, in other words, the greatest possible sexual liberty for male and the greatest possible limitation for women, which can coexist. A major distinction is thus created between the two classes of harlots and "virtuous women," into which two classes all women are distributed if the system is perfectly carried out. As a matter of fact, in most social groups under the successive stages of civilization, there has been a "borderline" class, never 
large, but rapidly increasing in size at the present time.

The typical rule of prostitution, although absent from some civilizations, is that the woman who "sins" once, if found out, becomes permanently a prostitute. Exceptions are made, in later forms of civilization, in favor of women belonging to certain small classes, but these exceptions are not of sufficient importance to alter the general conditions. Prostitutes are in general childless, except for the single "love child" which is in many cases the instrument through which the woman's "sin" is discovered, and through which, therefore, she is committed to harlotry. In total, the progeny of harlots are of small consequence.

Prostitution furnishes therefore a sink, into which certain lines of human descent are constantly vanishing. The types of woman absorbed in this sink include two of probable importance as regards their effect on the stock. These are, first: the feeble-minded, who, according to current statistics, are found in significant frequency among harlots and "delinquent" women;" and second, those women who are more like the male in the temporal course of sexual desire than is the

\footnotetext{
* Caution in evaluating these statistics is necessary. They are of course drawn from the relatively small class of "delinquents" who are caught; and of course the woman of lower intelligence is more apt to be caught than is the more intelligent "delinquent." To a lesser degree, the same
} consideration applies to the statistics on relative frequency of nymphomania. 
average woman, and are hence more apt to actively seek intercourse, or more apt to yield to the illicit solicitations of the male. The occurrence among prostitutes of a certain proportion of nymphomaniacs is not surprising.

The age-long drafting into the ranks of harlots of the more ardent women should theoretically give a slight advantage in reproduction to the "colder" types, and could thus have produced a modification in the average constitution of woman; which seems indeed to have occurred. While among savages, according to many accounts, women are more lustful, if anything, than men; among modern civilized peoples the rule is that aside from coquetry, woman yields rather than seeks. Her sexual desires are a flame which must be lighted from an external source, whereas the male's are self-igniting. Man's desire is always explicit, but woman's are usually implicit, becoming explicit only under the favorable stimulating influence-mental and physical-of the male. The manifestation of the implicit desire in extreme cases is coquetry, which is only an exaggeration of the normal tendency to encourage the male, that is, to submit herself to the stimulation, mental at first, which will eventually arouse her explicit desire. The beautifui reciprocity of the sexes herein exhibited must command our ad- 
miration by its efficiency in promoting Dame Nature's aims.

Prostitution has no such selective effect on the males as it has on the females. It may have a slight effect in delaying, or in exceptional cases obviating, marriage. But whereas prostitutes never constitute more than a small percentage of the female population, their patrons constitute an important percentage of the male population: estimates (admittedly unreliable) running as high as ninety per cent in America, and higher in Europe. Nor can it be said there is any less ultimate fecundicity among the more frequent male fornicators than among the less frequent, or among the minority who take monogamy seriously. Other vices, however, homosexuality in particular, do lessen reproduction by males of weak strains,* although having no probable effect on female reproduction.

The presumptive effect of prostitution on the average emotional constitution of woman can as reasonably be assumed to be a loss as a gain. If we could free ourselves from the still prevalent view of woman as property; if marriage could

*Against the Freudian supposition that homosexuality is a normal incident of the development of the individual, I wish to set the conjecture, at least as plausible, that it is the mark of an hereditary taint, where it is not produced by extremely pathological social conditions, and that even in these latter cases, it develops under the guidance of an influential tainted stock. Although homosexuality is frequent among women, that it acts as a preventive of marriage and child bearing in more than an inconsiderable number of cases does not seem probable. 
be put on a plan of equality; there would undoubtedly be a consensus of opinion that society loses by a repression of the emotional life of females. Hence, the only benefit we can assume from prostitution is the reduction of reproduction by the feeble-minded. And this, in contrast with the serious racial effects of venereal disease which prostitution facilitates: with the even more serious evil of unmated women which prostitution augments: and with the psychological effects on the men who resort to prostitutes-effects which have not been given due consideration as yet-is a contribution so small that it is not worth consideration.

\section{Practical Steps in Conservation}

Any consideration of the propagation of the most beautiful types involves a consideration of the standard of beauty; and as I have pointed out, there is a diversity in this respect, not only nationally, but to a lesser degree even within a single civilized nation. This diversity, however, is not a serious impediment, since any practical steps which might be taken would be based, not upon a narrow type-classification, but rather on a broad grouping of types including all divergencies which do not involve disregard of the fundamental principles of fitness.

In effect, we-are considering; at the most, not 
the extreme selection as carried out in stockbreeding, where a definite, narrowly defined character (such as speed, milk secretion, or color) is desired, even at the expense of other characters; but the elimination of the obviously unfit, and the promotion of the breeding of a wide range of more fit types: In so far as pasitive selection, as contrasted with elimination, is concerned, this can safely be accomplished by facilitating and fructifying the natural process of sexual selection-rather than-by arbitrary regulation.

In considering elimination, two questions are equally important: first, what classes of individuals should theoretically be eliminated? and second, what machinery of elimination is possible, and how far is it safe to allow this machinery to operate?

If we do not allow the second question to disturb us, the first question may readily receive a partial answer. Feeble-mindedness, hereditary insanity, and hereditary criminal tendencies (if such oecur) should-be nipped in all the buds they show: Individuals showing these traits definitely should not be allowed to reproduce. Diseases and organic weaknesses which are transmissible to offspring (if there be such diseases) should come under the same rigid ban. Although additions would need to be made to this list, the program indicated 
so far is so large that these additions might well be left to the indefinite future.

The actual adoption of measures for the elimination of the obviously unfit from participation in reproduction, offers at the present time difficulties which seem insuperable. Sterilization is the abstractly logical course to pursue, sinee it interferes with no function of the individual except the creation of children. But in addition to the psychological difficulties involved in social prejudices against this operation, there is a very real danger to be foreseen which can not be lightly set aside. If we could assume that the requisite machinery for the selection of those who should be sterilized would operate with perfect intelligence and without ethical lapses, we might view its introduction with equanimity. But such large chances are offered for ignorance and cupidity to work injustice that the scheme cannot possibly be accepted at the present time, whatever may be the conditions in some distant future.*

If sterilization were legally instituted at the present time, its practical administration would in all-probability be placed in the hands of the meddical profession as such (and the "as such" is here a very important consideration). The medical profession, in the United States at least, is a

\footnotetext{
* Legal provision for sterilization has been made in several states in the Union. Apparently, the provision has not been followed in practice to any considerable extent.
} 
very strongly organized guild, having the essential characteristics of the labor unions. It includes a large number of the most intelligent, scientific and morally estimable men in the nation; but its rank and file are properly ranked as skillful technicians and not above the middle-class average in intelligence and morality. The commission to such an organization of such sweeping control as is contemplated by the proponents of sterilization would be a political revolution of a most portentous nature. The assigning of complex-preblems-involving medieal and other factors, to the control of the medical profession as such, does, and under conditions such as the present, will, not-onty endanger the solution of these very problems,-but also introduce dangerous political situations-A similar statement could equally well be-made of any other organized trade or profession. If the time ever comes-when the control of sterilization could be committed to a nonprofessional body, employing the services of men of whatever professional skill may be needed, the possibility of systematic legal sterilization may become a live one. At present, it must be emphatically rejected.

Progress is possible towards the elimination of the unfit through the means. which have most contributed to all progress, namely, education and publicity. The elimination under consideration is 
an ideal, which must be kept constantly in view, in order that all social changes, legislative and otherwise, may receive consideration, as regards their influence, direct or indirect, upon the facilitation of progress towards it.

Aside from the elimination of individuals of undesirable heredity, there are measures of a quasi-eliminatory character which may be taken to guard against deterioration of stocks. In addition to rational hygienic measures against the spread of diseases in general, special precautions are needed against venereal diseases, since these most seriously threaten the virility of the race. With these diseases, sterilization would not be a sufficient protection, inasmuch as that operation does not preclude their transmission to nonsterilized individuals. It is imperative that there be absolute prevention of intercourse between infected and noninfected persons; and this prevention is a task of gigantic proportions. Its accomplishment would probably necessitate the imprisonment (or the equivalent) of every individual case of gonorrhea and syphilis. If recent conclusions that leprosy is also a venereal disease, transmissible during a long period before it becomes recognizable, are correct, the handling of this disease, in countries where it flourishes, presents especial difficulties, since the attempt to stamp it out would involve the enforcement of more drastic 
prohibitions against promiscuity than have ever been attempted.

In these cases again, education and publicity seem to be the chief available weapons at present. Minor legislation, such as severe punishment of individuals who can be shown to have infected others, and of-syphilitic individuals who become parents, are worthy of consideration, but economic and general social influences bearing on the situation should not be neglected.

If, by concerted efforts of the governments of the world, venereal diseases could be finally stamped out, no events in the Christian era would "be worthy to rank with this accomplishment except the defeat of the Mohammedans by Charles Martel and the defeat of the followers of the "good old German god" by Foch.

\section{INCEST AND INBREEDING}

In all stages of society there have been developed restrictions on mating which are conveniently described as incest-prohibitions. The wide variations in the tabus or conventions of this sort have given rise to much discussion among anthropologists and sociologists, but the universal principle on which these tabus are based is now quite clear. Whether the prohibition is against the mating of blood-relations of certain degrees, or against mating of persons socially related through com- 
mon name, or totem, or tribal subdivision, it is always of such a nature as to prevent the conjugation of persons-who are reared in close association or-intimacy; causing the individual to look for a sex-mate beyond the limits of his immediate "family." In many cases, the prohibition is retained long after the "family" life is so changed that the original reason has ceased to exist; as for example, is the case with the prohibition of the marriage of first cousins, who in many communities are no longer apt to be reared in greater intimacy than are children not blood-related at all. This persistence of conventions no longer useful is so common in society generally as to raise no special difficulties in understanding the incest prohibitions. In origin, these prohibitions are, without exception, conventions against the sex-mating of what may be designated as "house-mates."

The importance of incest-conventions needs no argumentative support. The sex-impulse, in spite of its strength, is easily directed by conventions: the assumption that such and such persons are not possible sex-mates, if inculcated early enough, is a very efficient preventive of sex-interest in those persons. Without such conventions, the probability of the too early maturation and excessive development of the sex-instinct is very great. Incest-prohibitions must therefore be religiously, if 
not blindly, preserved, if the future of the race is to be guarded.

Inbreeding, which is frequently confused with incest, is a radically different matter, although in particular cases the two conditions may overlap. The union of cousins is inbreeding, and may be incest, but the reasons for prohibiting it as incest have nothing to do with the bio-? logical results of the inbreeding. The popular notion that the incest-convention has grown up as a result of observation of the evil effects of inbreeding, or through an "unconscious" knowledge of such evil effects is entirely fallacious. The justification, moreover, of an outworn incest-convention of this sort, through an appeal to the supposed evil effects of inbreeding, is without proper foundation.

It is now well known that inbreeding has in itself no evil effects. Stocks do not deteriorate through consanguineous marriages, but strong points as well as points of weakness are accentuated. Feeble-mindedness furnishes a good illustration of the results of breeding. Some of the progeny of the union of a sound and a feebleminded parent, will be sound: but they carry in their germ-cells the "determinant" of feeblemindedness, and transmit it to a certain proportion of their own progeny. If two persons, both of whom carry this determinant, mate, the charac- 
teristic will reappear in certain of their progeny (that is, some of their children will be feebleminded) although the characteristic may have been latent for several generations. Obviously, parents who both come from feeble-minded stock are more apt to possess this determinant than parents of diverse stock: hence we see the feeblemindedness reappearing strikingly in certain cases of consanguineous marriages. The situation with regard to other weaknesses is similar. Marriage of cousins produces a significant number of deaf, or color-blind, or otherwise defective children because these defects were latent in the stock and are brought out by being transmitted through both parents. If the parents in such a case had each married persons not carrying the "determinant" of the defect in question, the defect might not have appeared, but (and this is the consideration which must not be forgotten), the determinant would have been transmitted to a certain proportion of their progeny, to reappear or produce the defect, in later generations when the conditions were favorable.

With regard to points of strength, the situation is the same as with points of weakness. High intelligence and longevity are actualized in the progeny of parents who both possess the determinant, whereas the determinant is in a large pro- 
portion of cases merely carried over to later generations if only one parent possesses it.

Instead of inbreeding being a racial evil, it may be a distinetly valuable means of progress. Strong strains are thereby conserved, and weaknesses in other strains are brought to the surface, so that they may be recognized and eliminated. This consideration applies not only to inbreeding, but the general mating of like with like, for the results of conjugation are the same when two persons - who mate both possess the same determinant, whether these persons are closely or remotely related in blood. If feeble-minded mate with feebleminded; if those who carry the determinant but do not show it, mate only with those who also carry the determinant, a large proportion of feeble-minded children will result from these unions. These children may then be institutionalized (if not sterilized) and prevented from reproducing, and their heredity thus eliminated. If, on the other hand, those of feeble-minded heredity mate largely with those of better heredity, the determinant is passed on, to make trouble in a larger degree in future generations, when like mates by chance with like.

For the welfare of the race therefore, like should be-encouraged to mate with-like, especially in so far as weaknesses are concerned, and inbreeding, in so far as there is no encouragement of 
incest, should have the ban against it removed. However unwise the removal, in England, of the prohibition against marrying a deceased wife's sister, may have been-because she is so frequently the husband's housemate - there is little reason, in America, in discouraging the marriage of first cousins. In the cases of aunt and nephew, and of uncle and niece, the incest-relation is possibly a distinct consideration.

\section{Improvement in Sexual Selection}

In passing to the consideration of improvement by positive selection of the best stocks we are harking back nearly twenty-three hundred years, from preventive medicine to eugenics. Plato, in the-Republic, outlines the first recorded plan for breeding a nation through careful selection of the most beautiful youths for parents, and punishment of unauthorized parents. Plato's scheme probably would not work, on account of its extreme paternalism, and its depersonalization as regards the indispensable feature of sexual union, namely, the offspring. It tends to reduce the individual's interest in cohabitation to the purely sexual level. The universal failure of institutional care of babies is a sound warning against allowing the sexual instinct to gain the ascendancy over the parental.

Plato was not fundamentally wrong in his the- 
ory of eugenics, any more than he was in other matters. The needs, after-elimination of the clearly unfit, are two First, to insure that marriages shall be made on the basis of mutual attraction of beauty alone, excluding all interference of national, family, social, religious, or economic motives. Second, to take care that the unions of the most fit shall be fruitful, and relatively more fruitful than those of the less fit.

The world at the present- time is overpopulated. Man has obeyed the injunction to "multiply and replenish the earth," and having succeeded in replenishing the globe in full and over full measure, has gone right on multiplying. Even wars and pestilences have not prevented the earth's population from becoming too numerous. And although pestilences may be mostly short-circuited by medical skill, war is inevitable when national domains are so overcrowded that further increase is possible only through depredation on, or conquest of, other peoples. If it had not been for the unnecessary multiplication of the German people, Germany would have had no occasion to attempt to conquer her neighbors, and would have had no occasion therefore to develop the philosophy of schrecklichkeit to make her barbarities possible.

The margin of living at the present time is very small. Land everywhere is becoming impoverished, and available new lands are becoming less. 
Even now, grazing lands are rapidly disappearing, with consequent shortage of beef and leather. Soon there will not be an extent of wheat lands sufficient to feed the world, and the inferior substitutes lately endured as a duty will be accepted as a necessity. When the whole world resorts to intensive farming, with no accessory regions of extensive cultivation, and no great wild areas for game and adventure, life for the majority of the people in our country and all others will take on the dull tinge it has in European peasant communities.

To make life profitable, we need vast forest areas, and vast areas which can lie fallow to recuperate. We need space for myriads of cattle and sheep, and for wild game. And we need to reduce our consumption of coal and oil and wood, rather than increase it.

The obvious relief measure is the decrease in births among the classes now unduly multiplying. And all that is needed to bring this about is a dissemination of knowledge concerning hygienic means of preventing conception. The classes from which our best parents are drāwn already possess some of this information and are already limiting-too much limiting, probably,-their offspring. The immediate and urgent need is to instruct the other classes, so that the disparity in 
propagation shall immediately be lessened, if not reversed.*

The converse reforms; the-increasing of the reproduction of the best specimens of the race; depends more largely than might be supposed upon the restriction of the propagation of the unfit. With a lessened pressure of population, economic and social situations change radically, and the very individuals who now deem families undesirable will find the possession and care of children to be the maximally desirable thing in life. Others, who eannot afford a family under the eeonomic situation now prevailing, will be able to maintain one without unduly relaxing the standard of living, when the pressure on means of sustenance becomes less.

The first step in the betterment of selection; the spreading of knowledge of preventive measures throughout the whole population; is the difficult one. In addition to the combination of ignorance and class-interest which this reform, like all others, has to combat, the opposition is so susceptible of political manipulation that it is almost impregnably intrenched. It is probable that not even the lessons of the German war will have much

\footnotetext{
*Instruction of the negroes alone, with perhaps some institutional assistance of a material kind, would help greatly in the solution of one of the most important of American social problems. There is no doubt that the negroes would welcome the ameliorative measure; certainly the negro women would.

Among the poorer white people, the lessening of the present prevalence of abortion would in itself be a valuable result.
} 
influence, and until the social and industrial crises now bearing down upon us have become actualities instead of threats the public will not wake up.

In addition to the general economic check to the reproduction of the so-called "better classes," there are positive psychosociological checks which operate selectively against the more beautiful women-preeisely the-women who ought to be selected for reproduction, not against it.

The more beautiful a woman, other considerations being equal, the greater her chance of -making a relatively-wealthy match-and her beauty may even overcome serious considerations of negative weight. The wealthier the match, under present conditions, the less the probability of her bearing children. Without wealth, social pretensions may have an even greater deterrent effect, for with wealth, social pretensions and ehildren are not positively incompatible whereas without wealth they are.

It is not worth while to gloss over facts, nor is it decent. Numbers of women of the most beautiful types are bought for a price, and that price is the assurance of being kept for life in a style and indolence which preclude (barring accidents) the satisfaction of the parental instinct. And even when tired of these mistresses, their consorts cannot discard them and take more normal women, for they (or their parents for them) have had the 
foresight to exact life contracts, legally enforcible, and not to be broken even legally, without the curse of the churches.

In many cases, the woman who surrenders her person in consideration of a life contract for her keep, performs no labor, not even caring for her own person; bears no children (unless inadvertently); and makes absolutely no return to society for the labor of many individuals expended upon her-except the personal return to her husband. Needless to say, "wives" of this sort are distinguished from mistresses, by the law merely.* They are more properly and accurately designated as hetairæ.

It would not be possible to do away with legalized hetairæ altogether, without radical revision of our entire economic system-for the whole marriage problem, while not entirely a problem in economics, is so hedged about with economic conditions that its solution must be largely economic. The conjugal relation should not in any case have an economic consideration. Any form of compensation for sexual relations is as much prostitution as if a fixed price in coin were exacted; and the legal form of prostitution is especially dangerous

\footnotetext{
*'The conventional standards of female morality, it must be understood, are matters of necessity and law, not of personal ethics. The implacable resentment of reputable women against the "weak sister" is not a result of abstract moral sentiment, but is precisely the feeling of the union laborer against the "scab" who cuts prices. And this solidarity of the women's "union" against lowering of the market, from life contract to less, has been an important protection to the sex as a whole.
} 
to the future of the race. It must not be supposed that by "sexual relations" the mere physiological act of copulation is meant. Many parasite wives are loved, and many extra-legal mistresses kept, and cherished because of their charming personalities and reciprocated affection; all this properly comes within the meaning of "sexual relations."

Not always does the husband of a parasite wife pay a price for her. Frequently she purchases him, and keeps him. But the outcome is the same in those cases, in which the "wife," already independent, uses her position to exempt herself from any social return.

The cure for the evil of nonreproduction of the fit and mated is not to be easily found. Perhaps it can be effected only by a fundamental revolution in the social attitude towards marriage. At present the-marriage of the "upper classes" is too much a matter of bargain and sale; among the "lower classes" too much a matter of slavery. The ideal marriage, in which there is a practical copartnership, involving the rearing of several children, and in which the husband and wife together contribute to industry, or art, or science, whether the contribution is directly credited to both or to the husband alone, is unfortunately found principally among the "middle classes." Those strata of society which practice real marriage will grow and strengthen, while those which 
practice the more oriental form will wither and decay.

Less numerous than the hetairæ of the class we have been discussing, but relatively more important because selected from these women who possess beauty in the highest degree, are public entertainers; - actresses, singers, chorus girls, and dancers. A certain small percentage of the female entertainers are presented because of qualifications other than beauty; for histrionic or terpsichorean ability or for mere voice quality, but the-majority are-selected on the basis of sexual attractiveness exclusively or in large part. Even on the "legitimate" stage, the demands made on the actress are not similar to those made on male players; the most successful actresses are with few exceptions those who most copiously display their personal charms-not merely of physique, but of all the qualities, including the subtler mental and emotional qualities, which affect and attract the better type of male. It is true that we have our great exceptions: Bernhardt and others; but it must also be admitted that while they, like Shakespeare, are revered, the larger group who merely exploit their pulchritude, are more popular. In musical comedy, which is in many ways the most important division of the stage, the actress without exceptional sexual attractiveness is soon eliminated. 
These professional entertainers are practically lost to posterity. While they are actively before the publie they do not-reproduce, and if they leave the stage or the cabaret for-marriage, it is usually marriage of the nonfertile-kind. Apparently, thousands of these selected females enter the profession every year; the very ones who, on Plato's plan would be picked out above all others for the perpetuation of the race being thus eliminated almost completely.*

The proportion of the female population which possesses distinctive beauty is never large in any community. If one will stand on a street which, like Fifth Avenue in New York, or Charles Street, in Baltimore, is a route of feminine parade, and count the number of women whom he or she would class as "really beautiful" the truth of this gen. eralization will be borne in on him. He will realize, in particular, that a majority vote of women would never favor a style of dress which should reveal the form any more than at present, and

\footnotetext{
* Some of the readers of my manuscript have expressed astonishment at my description of chorus girls and dancers as the type of high development. This astonishment is due to failure to understand my real point. Individually, many of these women may be of undeveloped mentality and coarse fiber: these are largely accidents of education and environment. Nevertheless, these same women may be racially of very high grade, that is, they may represent stock capable of high moral and mental education, as well as of excellent physique. The racial qualities, transmissible to progeny, it must be remembered, are independent of training. It must also be borne in mind, that $I$ am speaking only of the type of enter. tainer which is really well selected, that is, which has the high as well as the lower qualifications. Many chorus girls, as I specifically point out, are not thoroughly beautiful, but are selected on an anatomical basis alone. These, of course, would not be picked "above all others."
} 
would probably favor a return of a considerable distance on the road from crinoline. The percentage of women who would be even moderately presentable as barelegged dancers, regardless of dancing ability, is so low as to be shocking. From such considerations as these it is apparent that the removal from the racial streams of even the relatively small number of physically fit women absorbed by the entertaining profession, is a serious matter: One can readily imagine what would have happened in the development of trotting stock if there had been continual selection of the best specimens to be removed from breeding.

Fortunately, selection for the stage and the cabaret is not so efficiently done as it might be; the standards of beauty are to a certain extent determined by persons who are not good judges of feminine beauty; and hence the maximal harm is not accomplished. This is true at least of the selection of the majority of the entertainers typified by the chorus. Some of the choruses which are the most painstakingly selected are, on this account, less effective than others more casually chosen. Mere bodily proportion and skin texture has been emphasized at the expense of expression; the less important details of beauty have obscured the more essential. This, however, is because of the relative novelty of the complete exposure of 
the female body to the public gaze, and will pass off as such exhibition becomes more commonplace.

At first glance, the damage done-to the race by the selection of public entertainers from the female sex, seems incurable. The public will have its entertainment, and there will be more extensive selection and more efficient selection, rather than less. It is not however certain that the present results are necessary, and possibly with better economic conditions, and higher social ideals, we may have our beautiful entertainers and their progeny too. If for example, a girl goes on the stage at eighteen and at twenty-five retires, marries, and bears a number of children, no harm is done. If this were the normal life-history of dancers and chorus girls, their selection would tend to improve the racial stock, instead of causing deterioration. Unfortunately, the usual story at present is far from the realization of this ideal.

The profound changes now occurring in our industrial and domestic conditions are rapidly inereasing a sort of matrimonial antiselection which is relatively new in the world. With the entry of women in signifieant numbers into the arts, industries, and professions, a new nonparental class is established. Many self-supporting - women eventually marry, but many do not, and the permanently celibate class will probably increase in relative numbers in the future. To a certain ex- 
tent, the independent class is recruited from those who are low in the scale of beauty, and hence are "rejects" from the matrimonial market. If this were the case with all, the tendency of industrial feminism would be to improve the remaining stock; but conditions are not so simple. Many self-supporting women-how many it is impossible to estimate-have opportunities to marry,-but set their own standards of selection high, and are not_content to accept the partners of the grade offered. As a result not only are they lost to posterity, but the declined males mate with females lower in the scale of fitness, and thus a double damage is done to the stock.

No permanent good could conceivably result from checking the growth of industrial freedom of women. In the course of time-and not probably a long time either-the disorganization of the entire family system resulting from this freedom will render imperative sweeping industrial and social changes which, if we maintain our ideals, can be such as will reestablish family life on a higher plane, and remove many of the injustices which civilization has long tolerated.

That the economic freedom of women has effects even more fundamental than the production of a nonparental class, is evident to any one who dips beneath the surface of society. The "double standard" of morals, resulting partly from ancient 
necessities of guaranteeing paternity, and partly from the universal consideration of women as property, is dissolving at a rate faster than casual observation reveals. So long as woman had but one means of providing for herself, namely: the sale of her person; the double standard was easily maintained. The woman who once "sinned" (and was found out) could no longer command a price as a wife, and was obliged to sell herself as a harlot. The woman who now is employed, at a living wage, may do as she likes, provided she does not make her private life public; and is yet able to continue to support herself without falling into prostitution, since her employers pay her for her work, not for her "morality." One who understands the psychological principles which control the sexual instinct might-predict from these circumstances the changes which are actually occurring. From these principles also, we can surely foretell that the revolution, having gained a little more headway, will spread far beyond the class in which it originated.

The abolition of the "double standard" may be set down, as a revolution which, though not accomplished, is so far along that there is no possibility of checking it, whether we would like to do so or not. The proximate effects will doubtless be appalling, and yet there is little reason to fear 
that ultimately it will not lead to a sexual morality far higher than the present standard.

If the growing freedom of women does not lead to the recognition of childbearing as a contribution to the state- the state, in its permanency representing the interests of posterity-the-future offers little chance of racial betterment. If this recognition is gained, and with it is established the principle that the woman who relinquishes gainful occupation to bear children is entitled to adequate recompense therefor, racial betterment may be greatly furthered. But-sueh-furtherance depends alse upon the maintenance of the family life with all that it now implies and more, except the dependency of the wife on the husband; and if this family life be lost, the situation will undoubtedly be worse than at present. The detailed problems must be met as they arise, but they will be met successfully only if we keep our ideals alive, and determine our legal, economic, and social measures in conformity with them. Neither by ignoring conditions and directions of change, nor by applying ancient formulae to new facts, can we maintain social equilibrium and secure progress. New wine must be put in new bottles,. and the bottles must be ready when the wine needs bottling. 


\section{The Selection of Male Parents}

In the process of sexual selection in civilized lands, beèuty-has perhaps played a smaller rôle in determining the chosen males than it has in pieking out the female parents. The physical and mental characteristics of the male which are vital for the future of the race have been more and more overshadowed by his ability to provide adequately or luxuriously for wife and immediate offspring. To an increasing extent also, the material resources possessed by men come to be results of social accident, rather than of personal quality and efficiency of the types which are racially and socially desirable. If this last thesis is not true, then our whole system of free education, except the merely vocational training, is based on a gigantic fallacy.

Any man, however-lacking in personal qualifications may, if he has wealth,-marry a woman of high parental fitness, mental as well as physical. $\mathrm{He}$ may not be able to obtain certain particular women of this high type, but he is sure of finding at least one who will accept him, if he desires such a one. This is true-provided he has no glaring positive disqualifications; and even so, imperfections which are racially malignant, are-lesser obstacles than superficial ones; a syphilitic history or puny physique are less influential than the loss of a leg or an eye. 
In the various economic grades of society, incidental financial resources play their part in the selection of males. In the melodrama, the beautiful heroine in the end accepts the personally desirable, but poor, hero, to the discomfiture of the wealthy, but sexually undesirable, rival. In real life, what ought to occur does not occur so uniformly. Youth, in which the preservative forces of nature are more abundant, has more intelligence in regard to all the details of mating and in regard to many details in the rearing of children; but the reprehensible philosophy of age sicklies the flame of youth with its pale cast, even where it does not resort to the forces of authority and economic control.

War, with all its evils, has brought a freshening of the sexual interests of women, and lent its support to the natural tendency to select for the race. In the military profession in time of war, the male personal qualities which preserve the stock come once more into the prominence they possessed in less civilized societies, and from which the machine-like organization of modern industrialism has driven them. It may well be that these qualities have no fuller scope or power in modern armies than in modern civil life. This is immaterial. The fact is that the glamor of ancient methods of combat still hangs about the military service, and these personal qualities attain thereby 
a psychological interest of practical power.* As a matter of fact, the recruit tends to put on, with his uniform, a more primitive and sexually challenging behavior than he assumes as a civilian in the restraining circumstances of western society. To the women of the nation, male personality became, during the war, of paramount importance, and the conflicting values went almost completely into the discard. Whether this effect will be carried over into the postbellum period remains to be seen.

It is entirely improbable that a war of less than ten years' duration has any injurious effect upon the stocks of a hationf Cohelusions that the effects of short wars are damaging have entirely neglected the psychological factors, which are the most important of all. A war lasting throughout a generation would have quite different effects, and is not to be made the basis of arguments concerning briefer conflicts. The incidental benefits which war confers upon a nation are not reasons

\footnotetext{
* Since writing the above I have received the following interesting communication concerning the fascination of the uniform: "In a recent book I came across these sentences, which come nearer expressing my sentiments on the subject than anything I have ever read:- 'but now that we are at war, there has awakened in every woman the ancestral enthusiasm that her remote grandmother used to feel for the strong and aggressive beast.-Before a uniform they feel the humble and servile enthusiasm of the female of the lower animals before the crests, foretops, and gay plumes of the fighting males." "

"But there is another feeling" (my correspondent adds), "that men in uniform always awaken in women:- the desire to mother them. Why is that?" An almost universal expression of the maternal instinct towards the potential parent! But with some women, the dominant response to the uniform (and the conditions it symbolizes) may be best described as an increase in coquetry.
} 
for advocating war, but do indicate the things that it is desirable to procure in times of peace.

Another effect of war-or what appears as another effect, although intimately connected with the effects just discussed, is the general unsettling of sexual "morality" among the men in the mobilized forces, and the women who are brought into direct relation to these forces. The effect on the male seems to be produced by the greater sexual opportunities offered, ${ }^{*}$ and the greater security of the army life in strange surroundings. The effects of the war on certain elements of the female population in the United States were no less definite. The "lure of the uniform" was a real phenomenon. Undoubtedly this "lure" was much increased by its frequent and detailed discussion in the press, repeatedly suggesting to impressionable young women the opportunities and excuses offered them. Possibly many girls were convinced that if they did not feel the much discussed "lure" they were not normal. Nevertheless, there was a real psychological fact at the foundation of this growth.

It is probable that the emphasis on male personality, and the stirring, by the general excitement of the war, of primitive tendencies and in-

*The intense desire of officers and men for overseas duty, which grew after the first expeditions had gone over, was in a great many cases fanned by the current belief in the freedom of sexual life offered soldiers in France. 
stincts, played a part in this phenomenon of fascination. A larger part was played by the unsettling of social conventions and restraints. That girls and young women whose lives had been most formal should suddenly be permitted to be freefor-all dancing partners for men of most miscellaneous sorts, whose names even the girls often did not know, was possibly not important in itself; but it is a significant index of the terrific upheaval in social conventions which the war brought.

The rapid and expected shifting of personnel undoubtedly contributed its share to the unsettling of the moral bonds of women, as it did to that of the men. Women, surrounded by strange men, under conditions facilitating unaccustomed informality, and rapid personal acquaintance and selection; and knowing that these men are shortly to be moved away, with slight possibility for future reencounters; find the maximally favorable conditions for slipping the leash of continence. This effect was produced not only on reckless girls of the type which tend to go "astray" at all times, but also on more mature and more circumspect women who under ordinary peace conditions would never have considered such license as even a remote possibility for themselves.

Whether the fire of license which flamed during the war will contribute to other conflagrations 
of different origins, or whether it will die out leaving only its ashes and embers, remains to be seen. In either event, it will have left effects upon the problem of racial betterment. Sexual restraints once thrown off by the individual are seldom regained; sexual restraints thrown off by any important social group are regained only by a slow process of group-reconstruction if at all. This is an inevitable consequence of the nature of such conventions.

The overlimitation of families by married couples of desirable grade is apparently due less to the tendencies of the husbands than to those of the wives. It is a common fallacy to assume that the maternal instinct is far stronger than the paternal. The explicit desire for children is common to young men of the better type-and I believe, more common than among young women of corresponding grade. Children recognize this instinct and respond to its manifestations in a striking way. It is indeed something of which many a young man is rather ashamed-clearly because it is explicit, and a part of his normal sex impulse. The implicit effects of this instinct are even more remarkable, for it can be detected in the whole cycle of behavior which finally lands the man in matrimony. Whereas women have strong economic reasons for marrying, men as a rule have economic reasons against it: but although all the 
comforts of life can be secured more easily by the bachelor than by the benedict under modern conditions, the one great thing which can be secured only by marriage-namely, the possession of children-leads out of bachelorhood. This is especially true of the man who marries "for love" only.

The conservation of beanty is the problem of the present day and of all time. I have attempted to show that such conservation is not to be sought primarily through comprehensive governmental direction, nor legal restrictions; nor by blind adherence to the protective regulations of the past, however admirable these may have been. Laws, conventions, and economic conditions should be so shaped as to facilitate conservation, instead of hindering it; but this shaping, and the still greater work of active motivation is to be accomplished through education and publicity directed in the service of ideals kept continually vitalized; ideals of personal values, among which beauty, in the comprehensive mental and physical interpretation we have given it, is paramount. 

. 

. 


. 

. 
DEC 121994 
